\title{
ANOXIC BASINS OF THE NORTH-WESTERN PARATETHYS IN MESO-CENAZOI YU.O. Gavrilov
}

\section{АНОКСИЧЕСКИЕ БАССЕЙНЫ СЕВЕРО-ВОСТОЧНОГО ПЕРИТЕТИСА В МЕЗОЗОЕ-КАЙНОЗОЕ Ю.О. Гаврилов}

На протяжении мезозоя-кайнозоя в пределах С-В Перитетиса неоднократно возникали бассейны С аноксидными обстановками, которые различались по продолжительности существования, занимаемой территории, причинам возникновения. Эти бассейны можно подразделить на долгоживущие (несколько миллионов лет) и короткоживущие (десятки - первые сотни тысяч лет). К долгоживущим относятся майкопский и кумский бассейны, в которых степень аноксии со временем могла меняться. Аноксидные обстановки в обоих водоемах возникли, видимо, вследствие появления плотностной стратификации вод. Определенную аналогию в механизмах образования в них аноксии можно провести с Черным морем. Развитие аноксии в этих случаях имело региональный характер, хотя и было связано с некоторыми глобальными тектоническими и климатическими событиями. Аноксия в бассейнах такого типа, отчасти предохраняла ОВ от интенсивного окисления, но не способствовала образованию его высоких концентраций ( $\mathrm{C}_{\text {орг }}$ до нескольких \%). Аноксидные обстановки формировались одновременно с возникновением этих бассейнов и являлись их характерной чертой (автохтонная аноксия).

Короткоживущие аноксидные бассейны возникали в нормально аэрируемых водоемах в результате кратковременной вспышки биопродуктивности, как правило, органикостенного фитопланктона. Они существовали в течение времени действия факторов, которые обеспечивали цветение фитопланктона, а по завершении их действия аноксия исчезала, и бассейн возвращался к своему прежнему «доаноксийному» состоянию (автохтонная аноксия). Следы таких короткоживущих аноксидных бассейнов запечатлены в разрезах мела - раннего палеогена С-В Перитетиса. Примерами кратковременного развития аноксии на территории С-В Перитетиса являются глобальные события начала эоцена, большинство меловых аноксических событий, установленные в разрезах Восточного Кавказа. Признаками аноксии в такого рода отложениях является тонкая ламинация, отсутствие следов биотурбации и бентосной фауны, их обогащение редокс-чувствительными элементами, присутствие биомаркеров типа изорениератена, изменения в комплексах микроорганизмов и т.д. Причиной накопления в бассейнах значительных масс ОВ и появления аноксии было резкое усиление выноса с суши в море биофильных элементов вследствие быстрых эвстатических трансгрессий и взаимодействия наступающего моря с наземными ландшафтами. После завершения трансгрессии и прекращения поставки в водоем биофильных элементов цветение фитопланктона ослабевало и затем прекращалось вовсе; находившийся в наддонных водах сероводород окислялся и аноксия в бассейне исчезала. Существенную роль в поддержке цветения фитопланктона в неглубоких бассейнах оказывали процессы рециклинга этих элементов.

Сравнение между собой аноксических бассейнов С-В Перитетиса позволяет заключить, что обе гипотезы о причинах накопления повышенных количеств ОВ в осадках 1) о решающей роли аноксии, 2) о решающей роли биопродуктивности водоема, имеют право на существование, но а) приложимы к аноксидным бассейнам разного типа, б) обусловливают накопление существенно разных количеств ОВ в осадках.

Geological institute of the RAS, Moscaw, Russia

Геологический институт РАН, г. Москва, Россия 